\title{
Antimicrobial Proteins Isolated from the Teat Canal of the Cow
}

\author{
By K. G. HIBBITT, C. B. COLE \\ Institute for Research on Animal Diseases, \\ Compton, Newbury, Berkshire \\ AND B. REITER \\ National Institute for Research in Dairying, \\ Shinfield, Reading, Berkshire \\ (Accepted for publication 20 February 1969) \\ SUMMARY
}

Proteins which inhibited the growth of two strains of Staphylococcus aureus and one strain of Streptococcus agalactiae were isolated from the teat canal keratin of the cow. Electrophoresis of the proteins on polyacrylamide gels suggested that they were basic. They were separated into six bands at $\mathrm{pH} 3.0$ but gave only two bands at $\mathrm{pH} 4.5$ and two lines of precipitin after gel diffusion and immunoelectrophoresis at $\mathrm{pH}$ values between 4.5 and 8.5 . In the presence of the anionic polymers DNA or heparin, complexes were formed which were not inhibitory of bacterial growth. The isolated proteins and the whole teat canal keratin were completely free from lysozyme. Their role is discussed in relation to the natural defence mechanisms of the teat canal.

\section{INTRODUCTION}

The teat canal is generally regarded as a barrier to artificial and natural infections of the mammary gland (Murphy \& Stuart, I 953; Fincher, Hodges, Murphy \& Morse, 1956; Plastridge, 1958). Pathogens placed beyond the teat canal into the teat cistern invariably lead to infection (Murphy \& Stuart, 1954; Newbould \& Neave, 1965; Hibbitt \& Jones, 1967). The teat canal may function as a mechanical barrier due to its efficient sphincter muscles but, in addition, it has been reported to possess antimicrobial properties which can be attributed to the sebum-like material, called teat canal keratin, which probably originates from the heavily keratinized squamous epithelium (Murphy, 1959). Teat-canal keratin was reported to consist of up to $90 \%$ lipid and has been shown to inhibit the growth of streptococci in vitro (Adams \& Rickard, 1963), but the lipid content of the keratin and its role in natural resistance has now been disputed (Treese, Morse \& Levy, 1966). More recently cationic proteins have been isolated from teat-canal keratin and they strongly inhibited the growth of staphylococci and streptococci isolated from mastitic udders in vitro (Hibbitt \& Cole, 1968).

This paper describes some of the properties of the proteins isolated from teat canal keratin. 


\section{METHODS}

The isolation of antimicrobial protein fractions from teat-canal keratin. Teat-canal keratin was obtained from lactating and dry cows of the Institute herd by the 'reaming' procedure described by Murphy \& Stuart (I953); larger amounts came from cows slaughtered at the abattoir. All keratin samples were stored at $-20^{\circ}$ until used.

The keratin was extracted by a procedure based on the method of Zubay \& Wilkins (1962). Approximately $300 \mathrm{mg}$. tissue were homogenized for $2 \mathrm{~min}$. in $25 \mathrm{ml}$. $0.15 \mathrm{M}-$ $\mathrm{NaCl}$ in an MSE blender. The homogenate was centrifuged at $12,000 \mathrm{~g}$ (av.) for $20 \mathrm{~min}$. and the supernatant fluid discarded. The precipitate was resuspended in $25 \mathrm{ml}$. glass-distilled water, and an equal volume of $0.5 \mathrm{M}-\mathrm{HCl}$ containing $0.2 \mathrm{M}$-barium acetate was added slowly and mixed thoroughly. The mixture was rehomogenized for I min. in the barium acetate solution, stirred for I 5 min. and centrifuged at $20,000 \mathrm{~g}$ (av.) for $30 \mathrm{~min}$. The supernatant fluid was dialysed against four changes of 5 l. glass-distilled water for $48 \mathrm{~h}$. After dialysis the proteins were freeze-dried and chromatographed on a carboxymethylcellulose column equilibrated with an $0 \cdot \mathrm{I} M-$ acetate buffer ( $\mathrm{pH} 4 \cdot 2$ ); after exhaustive washing with the buffer they were eluted with $0.2 \mathrm{M}-\mathrm{HCl}$. The eluted proteins which appeared as a single peak were dialysed and freeze-dried. All operations were done at $4^{\circ}$.

Disc electrophoresis. The proteins were separated by electrophoresis in polyacrylamide gels at $\mathrm{pH} 3.0$ and $\mathrm{pH}_{4.5}$ by the procedure described by Narayan, Narayan \& Kummerow (I964). A buffer consisting of O.I M-tartaric acid +O.I Mformic acid containing $0.0 \mathrm{I} \mathrm{M}$-EDTA and $6 \mathrm{~m}$-urea was used for the separation at $\mathrm{pH} 3.0$. For the experiments at $\mathrm{pH} 4.5$ the same concentration of EDTA was added to an 0.1 M-acetate-buffer.

Preparation of proteins for assay. Approximately $2.0 \mathrm{mg}$. protein were shaken in $4 \mathrm{ml}$. $0.0 \mathrm{I}$ M-citric acid $+\mathrm{Na}_{2} \mathrm{HPO}_{4}$ buffer ( $\mathrm{pH} 7 \cdot 0$ ) containing $0.1 \mathrm{M}-\mathrm{NaCl}$. The undissolved protein was sedimented at $1500 \mathrm{~g}$ for $10 \mathrm{~min}$. and the protein content of the supernatant determined spectrophotometrically (Layne, I957). The volume of this solution was finally adjusted to give a protein concentration of $150 \mu \mathrm{g} . / \mathrm{ml}$.

Organisms. Cultures of two strains of Staphylococcus aureus (42D and 52 B phage type) were grown in Oxoid nutrient broth and Streptococcus agalactiae SI 3 (Pattison, I948) in Todd-Hewitt medium. After incubation at $37^{\circ}$ for approximately $6 \mathrm{hr}$ they were harvested while still in their logarithmic growth phase and diluted in physiological saline to give a count between 50 and 100 organisms $/ 0.02 \mathrm{ml}$. This bacterial suspension could be stored at $4^{\circ}$ for up to 2 days without deterioration.

Antimicrobial assay. The teat-canal proteins were assayed for inhibition of the test organisms by the procedure described by Hirsch (1958), with the exception that the colonies were counted in a Hannay counting chamber.

Lysozyme assay. Lysozyme was assayed by the procedure describe by Shugar (1952).

Preparation of antisera. Rabbits were immunized by a course of four intramuscular injections, given at weekly intervals, and consisting of $10 \mathrm{mg}$. of antimicrobial protein extracted from teat-canal keratin in $0.5 \mathrm{ml}$. of complete Freund's adjuvant (Difco). Three weeks after the last inoculation the sera were harvested.

Immunoelectrophoresis. The micro method of Scheidegger (1955) was used with $0.02 \mathrm{M}$-veronal, $0.004 \mathrm{M}$-EDTA buffer $\left(\mathrm{pH} \mathrm{8.6)}\right.$ or $0.05 \mathrm{M}-\mathrm{KH}_{2} \mathrm{PO}_{4}$ buffer $(\mathrm{pH} 4.5$ ). The applied potential was $75 \mathrm{~V} / \mathrm{cm}$. for I hr. 


\section{RESULTS}

The antimicrobial proteins extracted in this study constituted approximately $4-5 \%$ (wet weight) of the teat canal keratin. These proteins which are soluble in distilled water and dilute acids were subjected to polyacrylamide gel disc electrophoresis. At $\mathrm{pH} 4.5$ the proteins were resolved into two principal bands which moved towards

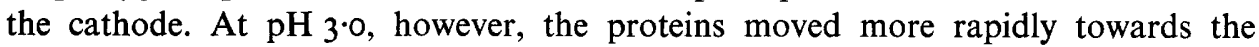
cathode and were resolved into 6 bands. The ultraviolet absorption curve (Fig. I) of the extracted proteins showed a characteristic pattern for material with minimal nucleic acid contamination, a major absorption peak occurring at $276 \mathrm{~m} \mu$.

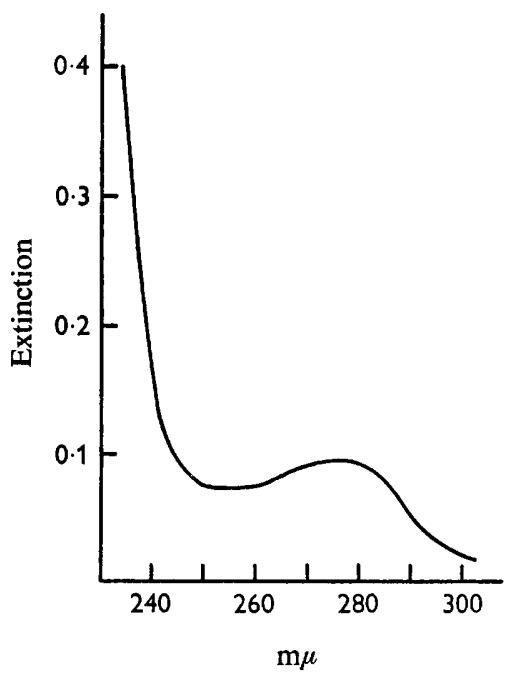

Fig. I

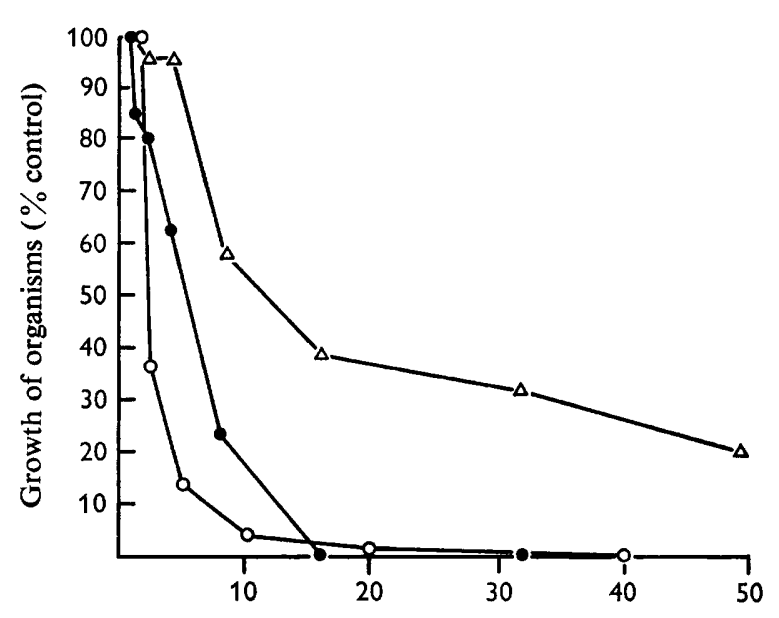

$\mu$ g. protein $/ \mathrm{ml}$.

Fig. 2

Fig. I. The ultraviolet absorption spectrum of antimicrobial proteins isolated from teatcanal keratin.

Fig. 2. The inhibitory effect of proteins isolated from teat canal keratin on the growth of micro-organisms. O-O, Staphylococcus aureus 42 D; - - , Staphylococcus aureus $52 \mathrm{~B}$; $\triangle-\triangle$, Streptococcus agalactiae S I 3 .

Inhibition of staphylococci and streptoccoci by teat canal proteins. The effect of various concentrations of the teat canal proteins on the growth of the test organisms is shown in Fig. 2. The growth of the two strains of Staphylococcus aureus was inhibited by $50 \%$ at a concentration of $2-5 \mu \mathrm{g}$. protein $/ \mathrm{ml}$. while Streptococcus agalactiae was inhibited at I $\cdot 5 \mu \mathrm{g} . / \mathrm{ml}$.

Removal of inhibition by anionic polymers. Electrophoresis had indicated that the proteins were basic; it was considered, therefore, that anionic polymers would combine with the teat-canal proteins and destroy their biological activity. The proteins were incubated at $37^{\circ}$ for I 5 min. with the anionic polymers DNA and heparin and assayed for their inhibitory activity. Table I shows that the inhibition of staphylococcal growth by the teat canal proteins at a concentration of $8 \mu \mathrm{g} . / \mathrm{ml}$. was progressively destroyed by increasing concentrations of both anionic polymers with complete destruction occurring at $3 \cdot 2 \mu \mathrm{g} . / \mathrm{ml}$. 
Absence of lysozyme in the teat canal protein preparations. Although staphylococci and streptococci are not susceptible to lysozyme (also a basic protein) in the sense that the cells are lysed, it is known that lysozyme can decrease the viable count of staphylococci (Kern, Kingkade, Kern \& Behrens, 195I). As this enzyme is known to be widely distributed in biological fluids and tissues it was thought to be of some interest to test the protein preparations from the teat canal for their lysozyme content. There was no lysozyme activity in the teat canal protein preparation or in the original keratin (Table 2).

Table I. The effect of DNA and heparin on the antibacterial activity of the teat canal proteins

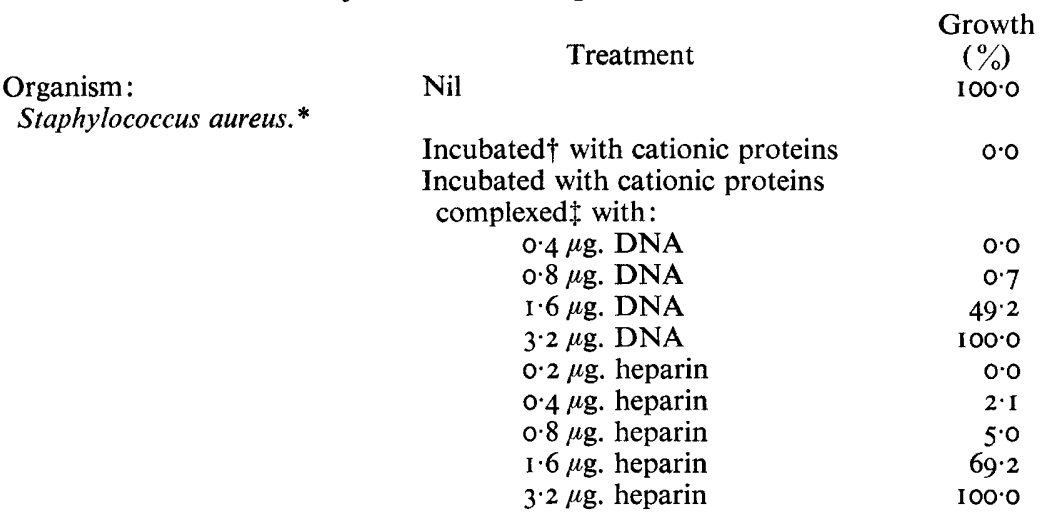

* Approximately 70 colony forming units of Staphylococcus aureus were incubated for $30 \mathrm{~min}$. in $1 \mathrm{ml}$. $0.0 \mathrm{I}$ M-citric acid $+\mathrm{Na}_{2} \mathrm{HPO}_{4}$ buffer $(\mathrm{pH} 7.0$ ) then grown in Oxoid nutrient broth containing I \% Davis agar.

$\dagger$ Staphylococcus aureus was incubated for $30 \mathrm{~min}$. in $\mathrm{I} \mathrm{ml}$. of the buffer described above containing $8 \mu \mathrm{g}$. of the cationic proteins.

$\ddagger$ The protein complex was prepared by incubating $8 \mu \mathrm{g}$. of the cationic proteins with DNA or heparin in I $\mathrm{ml}$. of the buffer described above at $37^{\circ}$ for $15 \mathrm{~min}$.

\section{Table 2. Test for lysozyme content of whole teat canal keratin} and partially purified antimicrobial proteins

Lysozyme
(units/mg. protein*)

Standard lysozyme

Whole teat canal keratin

Antimicrobial proteins from teat canal keratin

8600

0

0

* One unit of activity is equivalent to a decrease in absorbency at $450 \mathrm{~m} \mu$ of $0.00 \mathrm{I}$ per min. at $\mathrm{pH} 7.0$ and $25^{\circ}$.

Gel-diffusion tests. The agar gel-diffusion test which is normally performed at $\mathrm{pH} 7 \cdot 0$ suggested initially some degree of homogeneity of the protein since it showed only one line of identity at a concentration of $2.5 \mathrm{mg}$. $/ \mathrm{ml}$. against homologous antiserum. When the concentration of the protein was decreased to $1.25 \mathrm{mg} . / \mathrm{ml}$. there was an indication that two precipitin lines may have been present. This result was not sufficiently clear to record; on the other hand two lines could be expected since two bands were also identified in the electrophoresis studies at $\mathrm{pH} 4.5$. 
Immunoelectrophoresis. The double line which was thought to be present in the gel diffusion test at the lower concentration was confirmed by immunoelectrophoresis at $\mathrm{pH} 8.6$ (Fig. 3) since two arcs of precipitation were formed against the antiserum. Immunoelectrophoresis is normally not performed at a low $\mathrm{pH}$ because of the danger of precipitating the serum proteins and the possible streaking of the protein. Therefore it was impossible to study the effects of the antisera on the protein fractions separated at $\mathrm{pH} 3 \cdot 0$. On the other hand, at $\mathrm{pH}_{4} \cdot 5$, the $\mathrm{pH}$ value which separated the proteins into two principal bands on polyacrylamide gel, two arcs were formed which moved towards the cathode (Fig. 4).

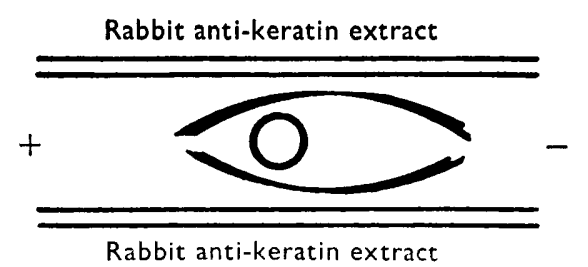

Fig. 3. Immunoelectrophoresis of teat canal antibacterial protein at $\mathrm{pH} 8 \cdot 6$.

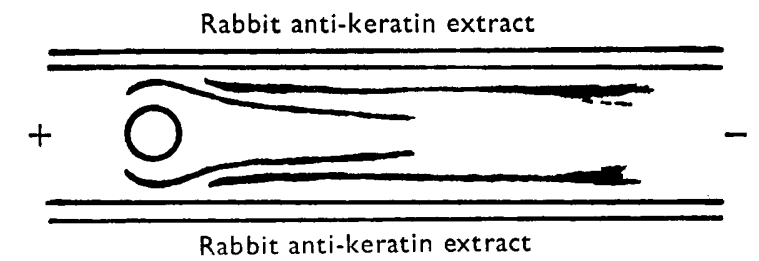

Fig. 4. Immunoelectrophoresis of teat canal antibacterial protein at $\mathrm{pH} 4.5$.

\section{DISCUSSION}

An investigation of the natural methods of protecting the bovine mammary gland against the invasion of micro-organisms may lead to a better understanding of the reasons why animals vary in their susceptibility to mastitis. The bacteriostatic activity of the lipids in the teat-canal keratin (Adams \& Rickard, 1963) is possibly only one of the many factors involved in natural defence since cationic proteins isolated from various tissues have been shown to possess bactericidal properties in vitro (Scarnes \& Watson, 1957; Hirsch, 1958; Zeya \& Spitznagel, I966). It is therefore conceivable that the cationic proteins isolated from the teat canal keratin may act in vivo as part of the protective mechanism against invasion of pathogens.

The behaviour of the isolated proteins during electrophoresis on polyacrylamide gels suggested that they contain a predominating number of positively charged groups. This possibility was further supported in the experiment, where it was shown that the antimicrobial activity of the proteins was lost when they were pretreated at $\mathrm{pH} 7 \cdot 0$ with negatively charged substances such as DNA or heparin. The positively charged proteins of teat-canal keratin would in all probability also be linked electrovalently to negatively charged components such as other proteins or nucleic acids, with a consequent loss of activity. This was borne out in a single experiment, not recorded in this paper, when it was found that isolated whole keratin had no anti- 
microbial activity. However, in a living teat canal, proteins are being synthesized continuously and would be free to bind to any negatively charged material including micro-organisms.

The complete absence of lysozyme in the isolated proteins and in whole teat-canal keratin was not surprising since Padgett \& Hirsch (1967) were unable to demonstrate its presence in tears, saliva, nasal exudates and peritoneal leucocytes obtained from a group of ten cattle. Furthermore, the morphological changes produced by lysozyme on Staphylococcus aureus were markedly different from those produced by the proteins isolated from teat-canal keratin (McMillan \& Hibbitt, 1969).

Although six bands of protein were separated on polyacrylamide gels at $\mathrm{pH} 3 \cdot 0$, at $\mathrm{pH} 4.5$ only two principal bands were observed. The resolution of closely related positively charged proteins would be less marked at higher $\mathrm{pH}$ values as their isoelectric points are approached. In the immunological studies therefore, which were necessarily carried out on the teat canal proteins at higher $\mathrm{pH}$ values, the separation of only two antigens is understandable.

The authors are grateful for the skilled technical assistance of Mrs W. M. Cole and Miss J. Waite.

\section{REFERENCES}

Adams, E. W. \& RiCKARD, C. G. (1963). The antistreptococcic activity of bovine teat canal keratin. Am. J. vet. Res. 24, 122.

Fincher, M. G., Hodges, H. G., Murphy, J. M. \& Morse, G. E. (I956). Mastitis research and control program. Rep. N.Y. St. vet. Coll.

HibBitT, K. G. \& Jones, G. W. (196\%). Quantitative deposition of bacteria within the teat canal of the goat. Vet. Rec. 80, 270.

Hibitt, K. G. \& Cole, C. B. (1968). The antimicrobial activity of teat canal cationic proteins. Biochem. J. 106, 39P.

Hirsch, J. G. (I958). Bactericidal action of histone. J. exp. Med. ro8, 925.

Kern, R. A., Kingkade, M. J., Kern, S. F. \& Behrens, O. K. (I95I). Characterisation of the action of lysozyme on Staphylococcus aureus and on Micrococcus lysodeikticus. J. Bact. 6r, 171.

LAYNE, E. (1957). Protein estimation by ultraviolet absorption. Meth. Enzymol. 3, 45I.

MacMillan, W. G. \& Hrbbitr, K. G. (1969). The effect of antimicrobial proteins on the fine structure of Staphylococcus aureus. J. gen. Microbiol. 56, 373.

MURPHY, J. M. (I959). The effect of certain mild stresses to the bovine teat canal on infection with Streptococcus agalactiae. Cornell Vet. 49, 411 .

Murphy, J. M. \& Stuart, O. M. (1953). Some results of the application of Streptococcus agalactiae (Cornell 48 strain) to the bovine teat canal by means of the Hadley-Wisconsin swab technique. Cornell Vet. 43, 465 .

Murphy, J. M. \& Stuart, O. M. (I954). The individual cow as a factor in Streptococcus agalactiae infection artificially induced by means of the Hadley-Wisconsin swab technique. Cornell Vet. 44, 268.

Narayan, K. A., Narayan, S. \& Kummerow, F. A. (I964). A modified disc electrophoresis method for animal blood serum proteins. J. Chromatog. 16, I87.

Newbould, F. H. S. \& NeAve, F. K. (1965). The response of the bovine mammary gland to an infusion of staphylococci. J. Dairy Res. 32, 163.

PadgetT, G. A. \& Hirsch, J. G. (1967). Lysozyme, its absence in tears and leukocytes of cattle. Aust. J. exp. Biol. med. Sci. 45, 569.

Pattison, I. H. (1948). Immunological studies with group B streptococci. J. Path. Bact. 6o, 219.

Plastridge, W. N. (1958). Bovine mastitis: A review. J. Dairy Sci. 41, II4I.

Scarnes, R. C. \& Watson, D. W. (1957). Antimicrobial factors of normal tissues and fluids. Bact. Rev. 2r, 273. 
ScheidegGer, J. J. (1955). Une microméthode de l'immunoelectrophorèse. Intern. Arch. Allergy appl. Immunol. 7, 103.

Shugar, D. (1952). The measurement of lysozyme activity and the ultraviolet inactivation of lysozyme. Biochim. biophys. Acta. 8, 302.

Treese, J. M., Morse, G. E. \& LeVY, C. (1966). Lipid analysis of bovine teat canal keratin. $J$. Dairy Sci. 49, I 240.

ZEYA, H. I. \& SPITZNAGEL, J. K. (I 966). Cationic proteins of polymorphonuclear leukocyte lysosomes. J. Bact. 91, 750.

Zubay, G. \& Wilkins, M. H. F. (1962). An X-ray diffraction study of histone and protamine in isolation and in combination with DNA. J. molec. Biol. 4, 444. 